\title{
PENGARUH BUDAYA ORGANISASI DAN PERILAKU BIROKRASI TERHADAP EFEKTIVITAS ORGANISASI: STUDI PADA DINAS-DINAS, BADAN-BADAN, KANTOR-KANTOR DAN SEKRETARIAT DI KABUPATEN SUMEDANG
}

\author{
Mulyaningsih \\ Universitas Garut \\ Email: mulyaningsih@uniga.ac.id
}

\begin{abstract}
Tujuan penelitian ini adalah untuk mengetahui pengaruh budaya organisasi dan perilaku birokrasi terhadap efektivitas organisasi pada Dinas-dinas, Badan-Badan, Kantor-kantor dan Sekretariat di Kabupaten Sumedang, baik secara parsial maupun seacara simultan. Metode penelitian yang digunakan dalam penelitian ini adalah survey dengan menyebarkan angket kepada 170 responden. Analisis data yang dibunakan dalam penelitian ini adalah analisis jalur untuk menguji hipotesis penelitian. Hasil penelitian membuktikan bahwa ada pengaruh yang positif dan signifikan antara budaya organisasi dan perilaku birokrasi terhadap efektivitas organisasi, baik secara parsial maupun secara simultan.
\end{abstract}

Kata Kunci: Budaya Organisasi, Perilaku Birokrasi, Efektivitas Organisasi.

\begin{abstract}
The purpose of this study was to determine the effect of organizational culture and bureaucratic behavior on organizational effectiveness in the Dinas-Dinas, Agencies, Offices and Secretariat in Sumedang Regency, both partially and simultaneously. The research method used in this study was a survey by distributing questionnaires to 170 respondents. Analysis of the data used in this study is path analysis to test the research hypothesis. The results of the study prove that there is a positive and significant influence between organizational culture and bureaucratic behavior on organizational effectiveness, both partially and simultaneously.
\end{abstract}

Keywords: Organizational Culture, Bureaucratic Behavior, Organizational Effectiveness.

\section{A. PENDAHULUAN}

Organisasi merupakan bagian penting dalam kehidupan manusia terutama di era globalisas yang serba bebas dan terbuka terutama dalam pergaulan dunia yang berkaitan dengan masalah-masalah ekonomi, politik, budaya dan iptek. Semua itu memberi arti, sekaligus peringatan bagi kehidupan manusia untuk memperoleh kebebasan dan manfaat dalam melakukan interaksi antara satu bagian dengan bagian yang lainnya. Demikian pula halnya dengan globalisasi dalam pergaulan internasional yang berdampak terhadap kehidupan masyarakat di Indonesia yang telah berubah dari polarisasi tradisional ke polarisasi modernisasi. Perubahan-perubahan itu akan berdampak pada, pola berpikir dan 
bertindak dari masyarakat yang menganut pola tradisional menjadi penganut pola modern yang memiliki ciri terbuka, konsumtif dan serba cepat dalam meraih segala sesuatu yang diinginkan.

Percepatan perubahan-perubahan di atas, mendorong ke arah perubahan perilaku masyarakat, baik secara individual maupun kelompok. Perubahan secara individual akan mengubah perilaku individu ke dalam tatanan kehidupan masyarakat, sedangkan perubahan perilaku secara kelompok memberi arti pada perubahan menyeluruh pada berbagai segmen organisasi termasuk di dalamnya organisasi birokrasi. Perubahan perilaku individu maupun kelompok pada organisasi birokrasi ini akan memberi makna penting bagi perubahan institusi secara menyeluruh yang berdampak pada perubahan global di suatu institusi di manapun berada.

Perilaku pada posisi lain dapat mempengaruhi lingkungan, sebaliknya pada kondisi tertentu lingkungan dapat mempengaruhi perilaku yang oleh Siagian (1994:174) disebut sebagai "kondisi interdependensi". Perilaku cenderung selalu berhubungan dengan lingkungan sekitar sebagai akibat dari adanya aktivitas organisasi. Sejalan dengan pandangan organisasi, Thoha (2008:120) menandaskan bahwa: Organisasi sebagai suatu organisme, yakni suatu sistem yang hidup dengan penekanannya pada unsur manusia sebagai pendukung utamanya, sehingga berakibat efesiensi dan efektivitas merupakan warna dari pencapaian tujuan dalam organisasi tersebut.

Sumber dari budaya organisasi mempengaruhi dan dipengaruhi oleh sebagian besar dari perilaku pendiri organisasi. Hal ini dipertegas oleh Kotter dan Heskett dalam Rusyani (2004:52) bahwa "sumber dari budaya organisasi, berasal dari beberapa orang, lebih sering hanya dari satu orang pendiri organisasi, orang tersebut akan mengembangkan strategi sesuai dengan lingkungan yang dikelolanya yang pada akhirnya akan menjadi kultur di dalam organisasi”.

Berdasarkan pandangan di atas, tampak bahwa perilaku birokrasi berkaitan erat satu sama lain dan saling memberi penguatan satu sama lainnya untuk memberi perubahan menyeluruh pada organisasi, baik organisasi publik maupun organisasi bisnis. Melalui budaya organisasi dan perilaku organisasi dapat meningkatkan kemampuan orang untuk berfikir, berlogika dan berpola pikir yang kompleks, dinamis dan konstektual yang diharapkan dapat berperan melahirkan sumber daya manusia yang beriman, bertaqwa kepada TuhanYang Maha Esa, berbudi pekerti luhur, cerdas, terampil, mandiri berkepribadian mantap serta memiliki rasa tanggung jawab kemasyarakatan dan kebangsaan. 
Kemajuan ilmu dan teknologi yang secara cepat, penyusutan sumber daya energi dan sumber daya alam lainnya, pertumbuhan persaingan nasional dan internasional, kegiatan kolektif pegawai serta masalah-masalah lainnya merupakan tantangan eksternal yang tidak bisa dielakan. Di sisi lain adanya tantangan internal yang berat, seperti menurunnya kedisiplinan dan kepuasan kerja pegawai. Tuntutan hak-hak pegawai serta budaya organisasi yang tidak kondusif merupakan masalah yang harus segera mendapat penanganan yang optimal.

Pergeseran kultur masyarakat dari masyarakat tradisional ke masyarakat industri, memiliki dampak yang mendasar terhadap arah pengembangan sumber daya manusia yang membawa implementasi terhadap perubahan budaya organisasi secara menyeluruh. Konteks ini merupakan masalah penting yang harus menjadi perhatian setiap organisasi dalam menghadapi persaingan yang demikian ketat untuk menjaga kestabilan dan kehidupan organisasi berkelanjutan. Inti permasalahan tersebut, bukan hanya pada pengadopsian teknologi yang cangih, tetapi yang terpenting adalah pada ketersediaan sumber daya manusia yang handal dan berkualitas yang didukung oleh kemampuan profesionalisme. Hanya organisasi atau lembaga yang memiliki sumber daya manusia yang berkualitas dan profesionalisme yang tinggi saja akan mampu ke luar dari persaingan global, sehingga dapat mengembangkan organisasi secara efektif.

Menghadapi tantangan di atas, maka setiap organisasi perlu mengembangkan strategi agar pegawai khususnya para birokrat selalu memiliki semangat dalam bekerja, termotivasi dan memiliki kepuasan dalam bekerja, sehingga senantiasa menghasilkan efektivitas kerja dan prestasi kerja yang tinggi dalam melaksanakan tugasnya. Dengan kata lain, peranan birokrasi dalam setiap organisasi atau lembaga harus dapat mengembangkan budaya organisasi, sehingga dapat mencapai efektifitas kerja yang optimal.

Efektivitas organisasi mengacu pada suatu kondisi yang menunjukkan tingkat keberhasilan dalam melakukan tugas untuk mencapai tujuan yang telah ditentukan. Dalam hal ini, dari perspektif kualitas dan kuantitas yang ditentukan sebelumnya sesuai dengan peraturan yang berlaku, sejauh mana organisasi melakukan tugas atau mencapai tujuan tugas. Selain itu, efektivitas organisasi mencakup proses kerja karyawan sehingga karyawan dapat secara konsisten melakukan beban kerja sesuai dengan jadwal atau tujuan waktu yang ditentukan. Hal ini dilakukan agar proses kerja dalam organisasi tidak akan memakan waktu lama, tetapi dapat diharapkan bahwa tujuannya benar, dengan kata lain, karyawan selalu dapat bekerja dengan benar dan memahami tanggung jawabnya dengan cermat. 
Mengenai efektivitas organisasi, Harits (2004:36) melakukan penelitian tentang efektivitas organisasi pungutan retribusi daerah pada dinas-dinas pendapatan daerah se-Jawa Barat yang menjelaskan bahwa Efektivitas organisasi tergantung pada pejabat terstruktur yang mengelola pekerjaan dengan mengatur secara hierarki koordinasi dan pengawasan setiap unit kerja. Hasil penelitian menunjukkan bahwa kurangnya sumber daya manusia dan fasilitas di kantor pajak daerah telah menyebabkan efektivitas organisasi dalam mengelola retribusi daerah pada Dinas Pendapatan Daerah di Jawa Barat kurang maksimal.

. Hasil penelitian di atas memotivasi peneliti untuk mempelajari secara mendalam pentingnya efektivitas organisasi dalam organisasi publik. Mengingat ketidaktepatan perilaku birokrasi dan rendahnya penerapan pemahaman budaya organisasi dalam organisasi publik, mereka saat ini menerima perhatian. Berdasarkan kondisi ini, para peneliti mencoba untuk mengevaluasi efektivitas organisasi di Dinas, Lembaga, Kantor dan Sekretariat Kabupaten Sumedang.

Hasil penelitian awal di lingkungan Dinas, Lembaga, Kantor dan Sekretariat di Kabupaten Sumedang, peneliti mendeteksi efektivitas organisasi rendah. Hal ini ditunjukkan oleh adanya indikator masalah yang menguatkan efektivitas organisasi rendah seperti kemampuan adaptasi rendah. Contohnya: pada Dinas Kebudayaan dan Pariwisata, dalam proses pengembangan seni budaya tradisional "kuda renggong" yang seharusnya menjadi ciri khas daerah bagi daya tarik wisata, dalam kenyataannya belum mengangkat seni daerah tersebut menjadi unggulan daerah. Hal ini ditunjukkan dari jumlah padepokan se-Kabupaten Sumedang berjumlah 34 padepokan yang dapat dibina hanya 15 padepokan mengingat rendahnya anggaran pengembangan seni budaya khas tersebut. Selain itu, kepuasan bekerja pegawai rendah, contohnya pada Dinas Pertanian, dalam pengembangan dan pembinaan buruh tani di beberapa pedesaan mengalami hambatan dalam proses pembinaan, sehingga dari 12 kelompok tani yang berasal dari 3 kecamatan hanya 6 kelompok tani yang mampu beralih dari bertani tradisional ke cara modern. Hal ini dikarenakan kinerja penyuluh yang belum optimal akibat dari rendahnya kepuasan penyuluh terhadap dana operasional untuk melakukan penyuluhan.

Masalah-masalah tersebut di atas disebabkan oleh budaya organisasi dan perilaku birokrasi pada Dinas, Lembaga, Kantor di lingkungan Kabupaten Sumedang yang belum dilaksanakan secara optimal untuk menjalankan tugasnya terhadap peningkatan efektivitas organisasi. Oleh karena itu, maka tujuan penelitian ini adalah untuk mengetahui pengaruh budaya organisasi dan perilaku birokrasi terhadap efektivitas organisasi pada Dinas-dinas, 
Badan-badan, Kantor-kantor dan Sekretariat di Kabupaten Sumedang, baik secara parsial maupun seacara simultan.

\section{B. KERANGKA TEORITIS DAN HIPOTESIS}

Organisasi sebagai artificial being juga mempunyai sifat yang sama yang biasa disebut sebagai karakter organisasi. Pengertian organisasi menurut Bakke dalam Kusdi (2009:5), bahwa definisi organisasi, adalah: A continuing system of differentiated and coordinated human activities utilizing,transforming, and welding together a specific set of human, material,capital,ideational, and natural resources into a unique problem-solving whole engaged in satisfying particular human needs in interaction with other systems of human activities and resources in its environment.

Berdasarkan pengertian diatas dapat dikatakan bahwa organisasi adalah suatu sistem yang dapat mengkaunter berbagai aktivitas manusia berupa sistem yang unik dari perpaduan beberapa sistem atau interaksi manusia dengan berbagai sumber daya dan lingkungan untuk dijadikan alat pemecahan masalah kebutuhan manusia itu sendiri.

Selanjutnya Morgan mempertegas hubungan ketiga unsur tersebut secara gamblang yang dikutip oleh Sobirin (2007:31) memberikan pandangan tentang metamorfosa organisasi terhadap perilaku dan budaya organisasi yaitu: Menganalogikan organisasi seolah-olah seperti benda atau objek lain dengan segala sifat yang melekat pada benda tersebut, seperti organisasi layaknya sebuah mesin,organisasi seperti organisasi hidup, organisasi seperti otak manusia. Analogi ini salah satunya-organisasi sebagai budaya akan menjadi landasan dalam memahami konsep budaya organisasi.

Pengertian tersebut lebih menengaskan kembali bahwa organisasi sebagai otak manusia yang dapat menghasilkan budaya organisasi sebagai suatu sistem. Hakikatnya budaya menurut Wallach dalam Rusyani (2004:59) dapat dikelompokan menjadi tiga, yaitu:

1. Birokrat: ditandai dengan karakter lingkungan kerja yang penuh tekanan, terstruktur, berjenjang, tertib, teratur, dan teregulasi dengan baik.

2. Inovatif: memberikan kebebasan para partisipan didalamnya untuk bebas berpikir, menyatakan pendapat, pikiran dan perasaan dan berkarya.

3. Suportif: menempatkan manusia sebagai titik sentral dalam organisasi.

Pengelompokan budaya tersebut di atas menitik beratkan manusia sebagai sentral dalam organisasi melainkan organisasi tersebut sebagai birokrasi atau struktur dengan 
lingkungan kerja organisasi tersebut. Pemikiran lain tentang perilaku akan berdampingan dengan budaya dikemukakan oleh Harrison dan Stokes (1992:1) bahwa:

Budaya mempengaruhi sebagian besar aspek kehidupan organisasi, seperti bagaimana keputusan dibuat, siapa yang membuatnya, bagaimana imbalan dibagikan, siapa yang dipromosikan, bagaimana orang diperlakukan, bagaimana organisasi memberi respon kepada lingkungannya. Ini membuktikan bahwa perusahaan kurang berbudaya, karena kurang memberikan respon kepada lingkungannya dalam hal ini kepada stakeholder.

Dapatlah disimak bahwa budaya organisasi pada dasarnya suatu upaya untuk mengikat perilaku individu dalam suatu organisasi sehingga memiliki satu kesatuan tindakan sesuai dengan pengertian. Harrison dan Stokes (1992: 1) menyatakan bahwa: "budaya organisasi adalah pola kepercayaan, nilai, ritual, mithos para anggota organisasi, yang mempengaruhi perilaku semua individu dan kelompok didalam organisasi”. Pendapat tersebut, beriringan dengan pandangan lain yang mempunyai kemiripan pemahaman budaya yang dikemukakan oleh Hofstede (1994:10) bahwa "budaya merupakan suatu program mental yang kolektif yang membedakan anggota suatu kelompok lainnya”.

Mempertajam pengertian budaya organisasi tersebut dapat dilihat dari nilai-nilai yang dianut individu atau pegawai sebagai landasan bertindak, seperti pengertian yang dikemukakan oleh Susanto (2000:4), sebagai berikut;

1. Budaya perusahaan adalah nilai-nilai yang menjadi pegangan SDM dalam menjalankan kewajiban dan merupakan landasan berperilaku dalam organisasi.

2. Budaya perusahaan adalah suatu nilai-nilai yang menjadi pedoman SDM untuk menghadapi permasalahan eksternal dan usaha penyesuaian integrasi kedalam organisasi sehingga mereka mengetahui bagaimana mereka harus bertindak atau berperilaku.

Selanjutnya penjelasan dari dimensi-dimensi nilai budaya ini sebagai berikut:

1. Kesenjangan kekuasaan, Senjang kekuasaan adalah dimensi yang menunjukan seberapa jauh pihak yang lemah dalam suatu masyarakat mau menerima ketidakseimbangan dalam pembagian kekuasaan yang ada dalam masyarakat dan mau mengangap hal itu sebagai suatu yang wajar.

2. Individualitas, Dimensi indvidualitas mempunyai dimensi lawan yaitu kolektivitas. Dimensi ini menggambarkan hubungan antara individu dengan komunitas dalam suatu masyarakat. 
3. Kemampuan Untuk Mengelakan Ketidakpastian. Kemampuan untuk mengelakan ketidakpastian adalah dimensi nilai budaya yang menunjukan seberapa jauh masyarakat tersebut dapat menjadi gelisah menghadapi situasi-situasi yang mereka anggap tidak menentu, tidak jelas, atau tidak dapat diramalkan dan seberapa jauh mereka berusaha menghindari situasi tersebut.

4. Maskulinitas. Maskulinitas dimensi lawannya adalah feminimitas.

Kesadaran akan sifat perbedaan pribadi yang terdapat diantara para pegawai sangat penting karena para pegawai berbeda memberikan tanggapan dengan cara yang berbeda pula atas usaha-usaha manajemen untuk mencapai usaha yang diarahkan pada tujuan. Dengan mengetahui perbedaan ini, maka efektivitas akan dapat diukur melalui suatu sistem yang bekerja secara stimulan dan sinergis. Menurut Zamroni (1992:154), perilaku adalah fungsi sikap, perilaku erat kaitannya dengan niat, sedangkan niat akan ditentukan oleh sikap dan norma subyektif. Niat seseorang untuk melakukan sesuatu ditentukan oleh dua hal, pertama sesuatu yang datang dari dalam dirinya yaitu sikap; kedua sesuatu yang datang dari luar yakni persepsi tentang pendapat orang lain terhadap dirinya dalam kaitan dengan perilaku yang diperbincangkan.

Dengan demikian, setiap perilaku berhubungan erat dengan sikap yang didasari oleh niat yang diendos dari dalam dirinya sendiri maupun datangnya dari luar dirisendiri. Perilaku yang berhubungan dengan birokrat akan tercermin dari standar kompetensi birokrat sebagai pejabat pemerintah yang harus memiliki kemampuan standar, baik standar inti maupun standar jabatan berupa motif, sifat, konsep diri, keterampilan, dan pengetahuan sebagai bentuk dari kinerja pegawai pemerintah.

Kemudian pengertian perilaku birokrasi pemerintah menurut Ndraha dalam Alamsyah (2004:50), yaitu; "Perilaku Birokrasi Pemerintah adalah menempatkan pegawai sebagai konsumen produk-produk pemerintah yang bekerja dengan penuh ketaatan, ketekunan kerja, pertanggungjawaban, kepuasan dan kedisiplinan". Pendapat tersebut mencerminkan bahwa perilaku birokrasi merupakan produk kegiatan yang diinginkan rakyat untuk menuju pemerintah yang good governance.

Thoha dalam Alamsyah (2003) mengatakan bahwa: Jika karakteristik individu berinteraksi dengan karakteristik birokrasi tersebut, akan timbulah perilaku birokrasi. Model perilaku birokrasi umumnya dapat digambarkan sebagai berikut:

Pandangan di atas, menjelaskan bahwa karakteristik kompetensi berkaitan dengan kesempatan untuk mengetahui kompetensi dalam konteks sosial sebagai output dari perilaku 
manusia yang merupakan interaksi dari tindakannya. Lebih lanjut Ndraha (1999:35) berpendapat bahwa: Birokrasi pemerintahan didefinisikan sebagai struktur pemerintahan yang berfungsi memproduksi jasa publik atau layanan-civil tertentu berdasarkan kebijakan yang ditetapkan dengan mempertimbangkan berbagai pilihan dari lingkungan.

Inti dari pemahaman efektivitas di atas, dinyatakan bahwa organisasi berhasil mendapat dan memanfaatkan sumber daya yang ada di lingkungannya dengan mencapai tujuan dan sasaran yang ingin dicapai dapat dikatakan organisasi itu telah efektif menjalankan tugasnya. Gibson dalam Andriani (1996: 38) mengemukakan bahwa :

Efektivitas berarti sesuatu yang berbeda bagi orang yang berbeda, apakah hal ini bersifat teoritis maupun praktis. Perbedaan dalam artinya menggambarkan satu ketaatan terhadap pendekatan tujuan, pendekatan teori sistem atau pendekatan multi constituency.

Efektivitas sangat ditentukan oleh adanya sumber daya yang baik, terutama menyangkut sumber daya manusia, baik ditingkat menejerial maupun pelaksana. Disamping itu, berbagai sumber daya pendukung, seperti organisasi dan fasilitas pendukung juga merupakan faktor yang penting dalam mendukung pencapaian efektivitas organisasi agar tujuan agar target, baik kualitas maupun kuantitas yang telah tercapai dengan baik sesuai dengan waktu yang telah ditetapkan.

Gibson dalam Harits (2004:109) menyatakan ada berbagai pandangan mengenai efektivitas, sebagai berikut:

1. Efektivitas individu yang menekankan pada (1) hasil karya pegawai atau anggota tertentu dari organisasi dan (2) prestasi kerja individu dinilai secara rutin lewat proses evaluasi hasil karya yang merupakan dasar kenaikan gaji, promosi dan imbalan lain yang tersedia dalam organisasi.

2. Efektivitas kelompok yang menekankan pada (1) bekerja secara bersama-sama dalam kelompok, dan (2) hasil yang dicapai jumlah kontribusi dari semua anggotanya.

3. Efektivitas organisasi tersendiri dari individu dan kelompok yang menekankan pada hasil karya yang lebih tinggi tingkatannya daripada jumlah hasil karya tiap-tiap bagiannya.

Price dalam Steers dalam Jamin (1980:192), mengemukakan variabel-variabel sebagai alat pengukur efektivitas dan sebagai variabel yang memperlancar atau membantu memperbesar kemungkinan tercapainya efektivitas organisasi sebagai berikut:

1. Kemampuan menyesuaikan diri/keluwesan/adaptasi

2. Produktivitas 
3. Kepuasan kerja

4. Kemampuan berlaba

5. Pencarian sumber daya

Sejalan dengan uraian di atas, Siagian dalam Harits (2004:114) mengajukan opini tentang mengenai faktor-faktor yang mempengaruhi efektivitas organisasi:

1. Suasana kerja yang mempromosikan pengembangan kreatif semua orang di organisasi.

2. Suasana kerja yang medorong keluarnya rasa senasib sepenanggunganan

3. Kondisi lingkungan internal dimana jiwa anggota-anggota suatu keluarga besar selalu diusahakan dapat berkembang.

4. Kondisi pekerjaan menyenangkan secara fisik, tempat kerja tidak menyesakkan napas, ventilasi cukup, tata ruang rapi dan bersih, fasilitas kerja yang layak dan sebagainya.

5. Terbangunnya suasana saling percaya bukan saling curiga.

6. Adanya kesepakatan mengembangkan kemampuan karyawan secara sistematis dan berencana yang dikaitkan dengan pengembangan karir dan digunakan sebagai wahana mempersiapkan karyawan dalam proses memikul tanggung jawab lebih besar dikemudian hari.

7. Karyawan berpartisipasi dalam proses pengambilan keputusan, terutama yang terkait dengan bidang tugas masing-masing.

Faktor-faktor di atas sangat penting dalam efektivitas kegiatan pengorganisasian untuk mencapai tujuan mereka. Berbagai pandangan seperti menurut Deesler (1991), Henry (1970) dan Gawa (1979) telah dikemukan di atas memberikan gambaran bahwa budaya organisasi dan perilaku birokrasi sangat mendukung efektifitas keorganisasian”.

Atas dasar pemahaman tersebut, maka kaitan antara variabel di atas dapat digambarkan pada gambar paradigma sebagai berikut: 


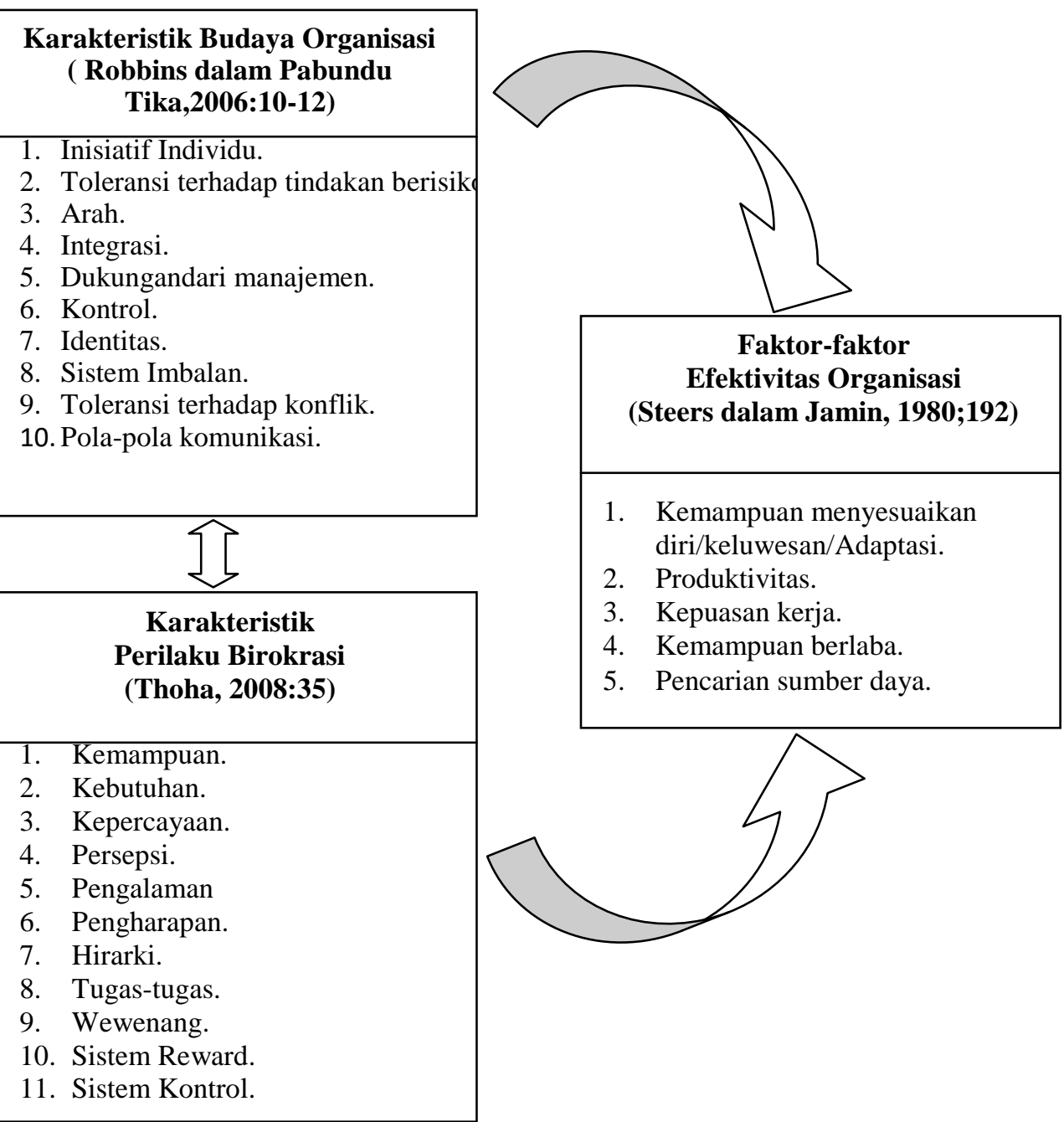

\section{Gambar 1 Paradigma Pemikiran tentang Hubungan Budaya Organisasi dan Perilaku Birokrasi dengan Efektivitas Organisasi \\ Setelah melihat paradigma pemikiran tentang Hubungan Perilaku Birokrasi dan} Budaya Organisasi dengan Efektivitas Organisasi, maka digambarkan pula hubungan masingmasing Karakteristik-karakteristik Budaya Organisasi dan Karakteristik Perilaku Birokrasi terhadap Faktor-faktor Efektivitas Organisasi sebagai berikut: 


\begin{tabular}{ll}
$\begin{array}{c}\text { Karakteristik Budaya Organisasi } \\
\text { ( Robbins dalam Pabundu Tika, } \\
\text { 2006:10-12) }\end{array}$ \\
\hline \multicolumn{1}{c}{ Inisiatif Individu. } \\
2. & Toleransi terhadap tindakan \\
& berisiko. \\
3. & Arah. \\
4. & Integrasi. \\
5. & Dukungandari manajemen. \\
6. & Kontrol. \\
7. & Identitas. \\
8. & Sistem Imbalan. \\
9. & Toleransi terhadap konflik. \\
10. & Pola-pola komunikasi. \\
\end{tabular}

Faktor-faktor

Efektivitas Organisasi

(Steers dalam Jamin, 1980:192)

1. Kemampuan menyesuaikan diri/keluwesan/Adaptasi.

2. Produktivitas.

3. Kepuasan kerja.

4. Kemampuan berlaba.

5. Pencarian sumber daya.

\section{Gambar 2 Paradigma Pemikiran tentang Hubungan Budaya Organisasi dan Efektivitas} Organisasi

\begin{tabular}{|ll|}
\hline $\begin{array}{c}\text { Karakteristik-Karakteristik } \\
\text { Perilaku Birokrasi } \\
\text { (Thoha 2008:35) }\end{array}$ \\
\hline 1. & Kemampuan. \\
2. & Kebutuhan. \\
3. & Kepercayaan. \\
4. & Persepsi. \\
5. & Pengalaman \\
6. & Pengharapan. \\
7. & Hirarki. \\
8. & Tugas-tugas. \\
9. & Wewenang. \\
10. & Sistem Reward. \\
11. & Sistem Kontrol. \\
\hline
\end{tabular}

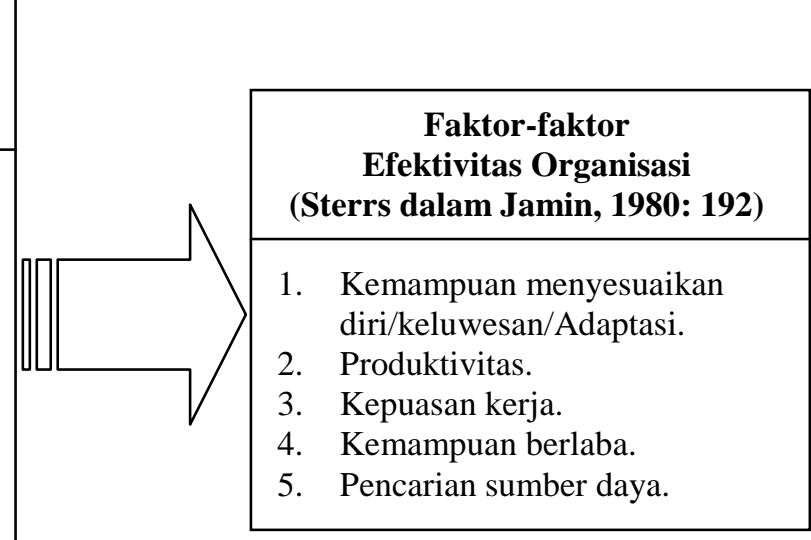

\section{Gambar 3 Paradigma Pemikiran tentang Hubungan Perilaku Birokrasi dan Efektivitas Organisasi}

Gambar di atas memperlihatkan paradigma pemikiran tentang Budaya Organisasi dan Efektivitas organisasi sebagai salah satu model hubungan dua variabel yang memberi kontribusi terhadap Efektivitas organisasi.

Berdasarkan identifikasi masalah dan kerangka pemikiran di atas, penulis mengajukan hipotesis utama sebagai berikut:

1. Budaya Organisasi dan Perilaku Birokrasi besar pengaruhnya terhadap Efektivitas Organisasi Dinas, Lembaga, Kantor dan Sekretariat di Kabupaten Sumedang.

2. Budaya Organisasi melalui: Karakteistik Inisiatif Individu, Karakteistik Toleransi terhadap Tindakan Berisiko, Karakteistik Arah, Karakteistik Integrasi, Karakteistik Dukungan dari Manajemen, Karakteistik Kontrol, Karakteistik Identitas, Karakteistik Sistem Imbalan, Karakteistik Toleransi besar pengaruhnya terhadap Efektivitas 
Organisasi Dinas-dinas, Badan-badan, Kantor-kantor dan Sekretariat di Kabupaten Sumedang.

3. Perilaku Birokrasi melalui: Karakteristik Kemampuan, Karakteristik Kebutuhan, Karakteristik Kepercayaan, Karakteristik Pengalaman, Karakteristik Persepsi, Karakteristik Pengharapan, Karakteristik Hierarki, Karakteristik Tugas-tugas, Karakteristik Wewenang, Karakteristik Sistem reward, dan Karakteristik Sistem kontrol besar pengaruhnya terhadap Efektivitas Organisasi Dinas, Lembaga, Kantor dan Sekretariat di Kabupaten Sumedang.

\section{METODE PENELITIAN}

Metode penelitian yang digunakan dalam penelitian ini adalah survey. Teknik pengumpulan data yang digunakan dalam penelitian ini adalah observasi, wawancara dan penyebaran angket. Jumlah populasi dalam penelitian ini adalah para pejabat struktural sejumlah 170 Responden terdiri dari 24 Dinas, Lembaga, Kantor dan Sekretariat Daerah di Lingkungan Kabupaten Sumedang. Setelah mengumpulkan data melalui kuesioner penelitian, analisis data dilakukan melalui tes statistik. Peneliti menggunakan analisis jalur (path analysis) untuk pengujian hipotesis.

\section{HASIL DAN PEMBAHASAN}

Secara deskriptif dilapangan budaya organisasi dan perilaku birokrasi sudah berjalan dan memberikan andil yang besar terhadap efektivitas organisasi, budaya organisasi lebih besar memberikan andil dibandingkan dengan perilaku birokrasi, artinya budaya organisasi harus menjadi prioritas perhatian para pejabat agar efektivitas organisasi seluruh instansi. Perilaku Birokrasi umumnya diwarnai dan termotivasi oleh budaya organisasi aparat yang mengadopsi dan mentrasformasikan kondisi yang datang dari lingkungan sebagai nilai-nilai leluhur berupa etika kabaheulaan sauyunan,sarendeuk saigel, sabobot sapihanean, penggunaan uniform solontong (pakaian pangsi hitam-hitam dan nyoren tas bubu) dan islamik pada diri birokrat.

Budaya organisasi dan perilaku birokrasi secara bersama-sama memberikan pengaruh yang kuat dan signifikan terhadap efektivitas organisasi pada Dinas, Lembaga, Kantor dan Sekretariat di Lingkungan Kabupaten Sumedang. Dalam konteks ini budaya organisasi lebih besar pengaruhnya dibandingkan perilaku birokrasi terhadap efektivitas organisasi sehingga 
budaya organisasi harus menjadi perhatian prioritas utama para pejabat agar efektivitas organisasi bejalan secara optimal.

Secara parsial budaya organisasi terdiri dari karakteristik inisiatif individu, karakteristik toleransi terhadap tindakan berisiko, karakteristik arah, karakteristik Integrasi, karakteristik dukungan dari manajemen, karakteristik kontrol, karakteristik identitas, karakteristik sistem imbalan, karakteristik toleransi terhadap konflik, karakteristik pola-pola komunikasi memberikan pengaruh yang kuat dan signifikan terhadap efektivitas organisasi Dinas, Lembaga, Kantor dan Sekretariat di Lingkungan Kabupaten Sumedang dengan karakteristik identitas dan karakteristik arah berpengaruh lebih kuat sedangkan karakteristik dukungan dari manajemen dan karakterisrik pola-pola komunikasi berpengaruh paling kecil terhadap efektivitas organisasi. Temuan penelitian menunjukan sangat perlu dikembangkan terus karakteristik identitas melalui indikator pencitraan pribadi, ciri khusus pribadi berupa nilai-nilai, simbol-simbol dan pemahaman perilaku aparat dalam mengidentifikasikan dirinya secara keseluruhan dalam organisasinya sesuai dengan arah kebijakan yang jelas serta perlu dikembangkan dukungan dan komunikasi hubungan dua arah dari atasan baik hubungan yang menyangkut hirarki kewenangan maupun persoalan diluar hirarki wewenang.

Secara parsial perilaku birokrasi yang terdiri dari karakteristik kemampuan, karakteristik kebutuhan, karakteristik kepercayaan, karakteristik pengalaman, karakteristik persepsi, karakteristik pengharapan, karakteristik hierarki, karakteristik tugas-tugas, karakteristik wewenang, karakteristik sistem reward, dan karakteristik Sistem kontrol memberikan pengaruh yang kuat dan signifikan terhadap efektivitas organisasi Dinas, Lembaga, Kantor dan Sekretariat di Lingkungan Kabupaten Sumedang dengan pelaksanaan karakteristik kemampuan dan karakteristik tugas-tugas berpengaruh sangat besar sedangkan karakteristik pengharapan dan karakteristik wewenang memberikan pengaruh paling kecil. Temuan penelitian menunjukan sangat perlu dikembangkan kemampuan dalam menguasai dan mengendalikan TUPOKSI, tingkat pemeliharaan kesehatan jasmani dan rohani dalam mendukung kelancaran bidang tugasnya sesuai dengan pembagian kerja berdasarkan pedoman kerja yang tersusun sebagai ukuran keberhasilan dari seorang pegawai serta perlu adanya mendelegasikan pekerjaan sebagai bentuk dari kepercayaan atasan kepada bawahannya agar setiap pegawai dapat bekerja sepenuh hati, bertanggung jawab bekerja keras sesuai dengan ukuran standar keberhasilan serta kelayakan kerja. 


\section{E. PENUTUP}

Budaya organisasi dan perilaku birokrasi secara bersama-sama memberikan pengaruh yang kuat dan signifikan terhadap efektivitas organisasi. Secara parsial budaya organisasi terdiri dari karakteristik inisiatif individu, karakteristik toleransi terhadap tindakan berisiko, karakteristik arah, karakteristik Integrasi, karakteristik dukungan dari manajemen, karakteristik kontrol, karakteristik identitas, karakteristik sistem imbalan, karakteristik toleransi terhadap konflik, karakteristik pola-pola komunikasi memberikan pengaruh yang kuat dan signifikan terhadap efektivitas organisasi. Secara parsial juga perilaku birokrasi yang terdiri dari karakteristik kemampuan, karakteristik kebutuhan, karakteristik kepercayaan, karakteristik pengalaman, karakteristik persepsi, karakteristik pengharapan, karakteristik hierarki, karakteristik tugas-tugas, karakteristik wewenang, karakteristik sistem reward, dan karakteristik sistem kontrol memberikan pengaruh yang kuat dan signifikan terhadap efektivitas organisasi.

\section{DAFTAR PUSTAKA}

Alamsyah, K. (2004). Perilaku Organisasi dalam Birokrasi Pemerintahan. Yogyakarta: CEPLAS dan Pustaka Raja.

Armstrong, M. (2003). Strategic Human Resource Managenent a Guide to Action. Jakarta: Garamedia.

Harrison, R., \& Stokes, H. (1992). Diagnosing Organizational Culture. San Francisco: Jossey-Bass-Pfeiffer

Harist, B. (2005). Teori Organisasi Jilid III. Bandung: Primapress.

Henry, N. (1970). Administrasi Negara dan Masalah-Masalah Kenegaraan. Jakarta: Rajawali Pers.

Ndraha, T. (2003). Budaya Organisasi. Jakarta: Rineka Cipta.

Robbins, S. P. (2006). Perilaku Organisasi. Jakarta: Indeks.

Rusyani, E. 2004. Pengaruh Budaya Organisai, Orientasi Etika, Orientasi Stretejik dan Implementasi Strategi terhadap Kinerja Keuangan Perusahaan Manufacture (Studi pada Perusahaan Manufacture dan Minuman di Indonesia). Bandung: Program Pascasarjana UNPAD.

Siagian, S. P. (1994). Filsafat Organisasi. Jakarta: Gunung Agung.

Sobirin, A. (2007). Budaya Organisasi. Yogyakarta: UPP STIM YKPN.

Steers, R. M. (1980). Efektivitas Organisasi. (Kaidah Tingkah Laku). Jakarta: Erlangga.

Sugiyono. (1992). Pengantar Metode Penelitian Administrasi. Bandung: Armico.

Thoha, M. (2008). Perilaku Organisasi, Konsep Dasar dan Aplikasinya. Jakarta: Raja Grafindo Persada.

Zamroni. (1992). Pengantar Pengembangan Teori Sosial. Yogyakarta: Tiara Wacana. 